\title{
TITLE:
}

\section{Dissolution Behavior of Lithium Oxide in Molten LiCl-KCl Systems}

$\operatorname{AUTHOR}(\mathrm{S})$ :

Kado, Yuya; Goto, Takuya; Hagiwara, Rika

\section{CITATION:}

Kado, Yuya ... [et al]. Dissolution Behavior of Lithium Oxide in Molten LiCl-KCl Systems. Journal of Chemical \& Engineering Data 2008, 53(12): 2816-2819

ISSUE DATE:

2008-12-11

URL:

http://hdl.handle.net/2433/255895

\section{RIGHT:}

This document is the Accepted Manuscript version of a Published Work that appeared in final form in Journal of Chemical \& Engineering Data, copyright @ American Chemical Society after peer review and technical editing by the publisher. To access the final edited and published work see https://doi.org/10.1021/je800540c.; This is not the published version. Please cite only the published version.; この論文は出版社版でありません。引用の際には出版社版 をご確認ご利用ください。 


\title{
Dissolution behavior of lithium oxide in molten LiCl-KCl systems
}

\author{
Yuya Kado*, Takuya Goto, Rika Hagiwara \\ Department of Fundamental Energy Science, Graduate School of Energy Science,
}

Kyoto University, Yoshida-honmachi, Sakyo-ku, Kyoto 606-8501, Japan

*Email : yuuya-kado@t02.mbox.media.kyoto-u.ac.jp 


\section{Abstract}

The solubility of lithium oxide was measured in molten $\mathrm{LiCl}-\mathrm{KCl}$ containing 58.5 ,

75, 90 and $100 \mathrm{~mol} \% \mathrm{LiCl}$ in the temperature range from 673 to $923 \mathrm{~K}$. The melt with

higher content of $\mathrm{LiCl}$ has higher solubility of $\mathrm{Li}_{2} \mathrm{O}$. The neat $\mathrm{LiCl}$ has highest solubility of

$\mathrm{Li}_{2} \mathrm{O}$ and it is $12.0 \pm 0.2 \mathrm{~mol} \%$ at $923 \mathrm{~K}$. The estimated standard formal potential of $\mathrm{O}_{2} / \mathrm{O}^{2-}$

increases linearly as the temperature decrease and the increase of the mole fraction of $\mathrm{LiCl}$. 


\section{Introduction}

Electrochemical reduction processes in molten salts have been studied for metal

refining and nuclear fuel reprocessing ${ }^{1,2}$. One of the most important achievements expected

for the improvement of the efficiency of the process is the development of an inert anode.

In our previous study, a boron-doped diamond (BDD) electrode was found to possess

excellent properties for this purpose ${ }^{3}$. In addition to the electrode materials, high solubility

of oxides in the melts is essential for fast electrochemical reduction of metal oxides with

high efficiency ${ }^{4}$. Molten $\mathrm{LiCl}$ and $\mathrm{CaCl}_{2}$ are strong candidates of the melts that satisfy the above requirement. Because of their high solubilities of oxides ${ }^{2,5}$, reduction of metal oxides has been achieved chemically and/or electrochemically in these melts ${ }^{2,6}$. However, high melting temperatures of $\mathrm{LiCl}$ and $\mathrm{CaCl}_{2}$ are disadvantageous for the process. Lower temperature operation has advantages such as lower corrosive and thermal damages to the 
vessels and electrode materials. Thus molten salts that have high solubility of oxides at lower temperatures are indispensible for the reduction processes of metal oxides although

few reports are so far available on this subject. In this study, the temperature dependence of solubilities was investigated in molten $\mathrm{LiCl}-\mathrm{KCl}$ systems with an electrochemical method. The compositions of $\mathrm{LiCl}-\mathrm{KCl}$ melts were selected referring the reported binary phase diagram $^{7}$.

\section{Experimental Section}

A glassy carbon rod (Tokai Carbon) was used as an anode material for cyclic voltammetry when it was used as an anode. The cathode materials were also glassy carbon rods at temperatures higher than $823 \mathrm{~K}$ while aluminum plates (99.2 \%, Nilako Corp.) were used at lower than $823 \mathrm{~K}$. The reference electrode was $\mathrm{Ag}^{+} / \mathrm{Ag}$ electrode. A silver wire (99.99 \%, Japan Metal Service) was immersed in the LiCl-KCl melt of each composition 
containing $0.5 \mathrm{~mol} \% \mathrm{AgCl}(99.5 \%$, Wako Pure Chemical Co. Ltd.) which was set in a Pyrex glass or mullite tube. The potential of the reference electrode was standardized against the $\mathrm{Li}^{+} / \mathrm{Li}$. A nickel wire as a current collector was immersed in melted lithium metal to measure the potential of $\mathrm{Li}^{+} / \mathrm{Li}$ against $\mathrm{Ag}^{+} / \mathrm{Ag}$.

Reagent-grade LiCl (Aldrich-APL $99.99 \%$ ), KCl (Aldrich-APL $99.99 \%$ ) and eutectic mixture of LiCl-KCl (Aldrich-APL $99.98 \%$ ) were used for the melt. The solubility of lithium oxide $\left(\mathrm{Li}_{2} \mathrm{O}\right.$, Aldrich. $\left.97 \%\right)$ was measured in $\mathrm{LiCl}, \mathrm{LiCl}-\mathrm{KCl}$ mixtures of following compositions; $\mathrm{LiCl}: \mathrm{KCl}=90: 10,75: 25,58.5: 41.5$ (eutectic). The experimental temperature range was 673 to $923 \mathrm{~K}$. All the experiments were conducted in a globe box filled with Ar gas dried and deoxygenated by a gas purifier (MIWA, MS3-H60SN). The concentration of water and oxygen gas in the atmosphere were kept less than $1 \mathrm{ppm}$.

Electrochemical measurements were performed using an electrochemical measurement system (HZ-3000, Hokuto Denko Corp.). 


\section{Results and discussion}

Temperature dependence of the solubility of lithium oxide in molten $\mathrm{LiCl}-\mathrm{KCl}$

Figure 1 shows the cyclic voltammogram in the positive potential region obtained in an eutectic $\mathrm{LiCl}-\mathrm{KCl}(58.5: 41.5)$ melt containing various amounts of $\mathrm{Li}_{2} \mathrm{O}$ at $773 \mathrm{~K}$ using a glassy carbon rod electrode. A sharp increase in anodic currents was observed at about $2.0 \mathrm{~V}$ (vs. $\mathrm{Li}^{+} / \mathrm{Li}$ ). This current is attributed to the evolution of carbon dioxide ${ }^{8}$.

$$
\mathrm{C}+2 \mathrm{O}^{2-} \rightarrow \mathrm{CO}_{2}+4 \mathrm{e}^{-}
$$

The peak currents corresponding to $\mathrm{CO}_{2}$ evolution plotted against the amount of $\mathrm{Li}_{2} \mathrm{O}$ added in the melt are shown in Figure 2. The current increased almost linearly as the increase of the amount of $\mathrm{Li}_{2} \mathrm{O}$ added and finally showed a constant value when the melt was saturated with $\mathrm{Li}_{2} \mathrm{O}$. As a result, the solubility of $\mathrm{Li}_{2} \mathrm{O}$ in eutectic $\mathrm{LiCl}-\mathrm{KCl}$ at $773 \mathrm{~K}$ is 
determined to be $1.12 \mathrm{~mol} \%$. Intersecting point of the two lines shown in the figure was chosen as a saturation point. In the same manner, the solubilities of $\mathrm{Li}_{2} \mathrm{O}$ were determined at $673,723,773$ and $823 \mathrm{~K}$. They were $0.708 \pm 0.055,0.966 \pm 0.031,1.14 \pm 0.05$ and 1.32 $\pm 0.53 \mathrm{~mol} \%$, respectively. The error value denotes the $95 \%$ confidence interval. The solubility of $\mathrm{Li}_{2} \mathrm{O}$ was also determined in the neat $\mathrm{LiCl}, \mathrm{LiCl}-\mathrm{KCl}$ mixtures; $\mathrm{LiCl}: \mathrm{KCl}=$ $90: 10$ and $75: 25$. The results are summarized in Figures 3 and 4 The temperature dependence of the solubility product, $K_{\mathrm{sp}}$, is given by the empirical equations in Table 1 , where $T$ is the absolute temperature. $K_{\mathrm{sp}}$ is determined by the equation (2) using the mole fraction of lithium ion, $X_{\mathrm{Li}^{+}}$, and that of oxide ion, $X_{\mathrm{O}^{2-}}$. The solubility of $\mathrm{Li}_{2} \mathrm{O}$ increases with the elevation of the temperature of the melt and the increase of the mole fraction of $\mathrm{LiCl}$ in the melt.

$$
K_{\mathrm{sp}}=X_{\mathrm{Li}^{+}}^{2} \cdot X_{\mathrm{O}^{2-}}
$$

Thermodynamical study on the standard formal potential of $\mathrm{O}_{2} / \mathrm{O}^{2-}$ 
The standard formal potential of $\mathrm{O}_{2} / \mathrm{O}^{2-}, E_{\mathrm{O}_{2} / \mathrm{O}^{2-}}^{0^{\prime}}$, was calculated and estimated

from the results obtained from the measurement of the solubility. Oxygen electrode reaction

and the Nernstian equation in molten salts are described as follows;

$$
\begin{aligned}
& \frac{1}{2} \mathrm{O}_{2}+2 \mathrm{e}^{-}=\mathrm{O}^{2-} \\
& E_{\mathrm{O}_{2} / \mathrm{O}^{2-}}=E_{\mathrm{O}_{2} / \mathrm{O}^{2-}}^{0}+\frac{R T}{2 F} \ln \frac{f_{\mathrm{O}_{2}}^{1 / 2}}{a_{\mathrm{O}^{2-}}}
\end{aligned}
$$

where $R$; the gas constant, $F$; the Faraday constant, $f_{\mathrm{O}_{2}}$; the fugacity of $\mathrm{O}_{2}, a_{\mathrm{O}^{2-}}$; the activity of $\mathrm{O}^{2-}, E_{\mathrm{O}_{2} / \mathrm{O}^{2-}}^{0}$; the standard potential of $\mathrm{O}_{2} / \mathrm{O}^{2-}$. Equation (4) is described as below using the fugacity coefficient of $\mathrm{O}_{2}, \gamma_{\mathrm{O}_{2}}$, the activity coefficient of $\mathrm{O}^{2-}$ anion, $\gamma_{\mathrm{O}^{2-}}$, and the pressure of $\mathrm{O}_{2}, \quad P_{\mathrm{O}_{2}}$.

$$
E_{\mathrm{O}_{2} / \mathrm{O}^{2-}}=E_{\mathrm{O}_{2} / \mathrm{O}^{2-}}^{0}+\frac{R T}{2 F} \ln \frac{\left(\gamma_{\mathrm{O}_{2}} P_{\mathrm{O}_{2}}\right)^{1 / 2}}{\gamma_{\mathrm{O}^{2-}} X_{\mathrm{O}^{2-}}}
$$

Consequently $E_{\mathrm{O}_{2} / \mathrm{O}^{2-}}^{0}$ is given by the equation:

$$
E_{\mathrm{O}_{2} / \mathrm{O}^{2-}}^{0}=E_{\mathrm{O}_{2} / \mathrm{O}^{2-}}^{0^{\prime}}+\frac{R T}{2 F} \ln \frac{P_{\mathrm{O}_{2}}^{1 / 2}}{X_{\mathrm{O}^{2-}}},
$$


where $E_{\mathrm{O}_{2} / \mathrm{O}^{2-}}^{0^{\prime}}$ is the standard formal potential of $\mathrm{O}_{2} / \mathrm{O}^{2-}$, which is given by the following

equation.

$$
E_{\mathrm{O}_{2} / \mathrm{O}^{2-}}^{0^{\prime}}=E_{\mathrm{O}_{2} / \mathrm{O}^{2-}}^{0}+\frac{R T}{2 F} \ln \frac{\gamma_{\mathrm{O}_{2}}^{1 / 2}}{\gamma_{\mathrm{O}^{2-}}}
$$

Now, when a $\mathrm{LiCl}-\mathrm{KCl}$ melt is saturated with $\mathrm{Li}_{2} \mathrm{O}$, a solution equilibrium shown in the equation (8) is achieved and the standard free energy change of the reaction (8), $\Delta G^{0}(8)$, can be calculated using the activity of the $\mathrm{Li}+$ cation, $a_{\mathrm{Li}^{+}}$.

$$
\begin{aligned}
& 2 \mathrm{Li}^{+}+\mathrm{O}^{2-}=\mathrm{Li}_{2} \mathrm{O}(\mathrm{s}) \\
& \Delta G^{0}(8)=R T \ln \left(a_{\mathrm{Li}^{+}}^{2} \cdot a_{\mathrm{O}^{2-}}\right)
\end{aligned}
$$

Here we introduce the standard formal free energy, $\Delta G^{0^{\prime}}(8)$, described by the equation:

$$
\Delta G^{0^{\prime}}(8)=\Delta G^{0}(8)-R T \ln \left(\gamma_{\mathrm{Li}^{+}}^{2} \cdot \gamma_{\mathrm{O}^{2-}}\right)
$$

where $\gamma_{\mathrm{Li}^{+}}$is the activity coefficient of $\mathrm{Li}^{+}$cation ${ }^{9}$. Thus $\Delta G^{0^{\prime}}(8)$ is given by the following equation using the mole fraction of $\mathrm{Li}^{+}$cation.

$$
\Delta G^{0^{\prime}}(8)=R T \ln \left(X_{\mathrm{Li}^{+}}^{2} \cdot X_{\mathrm{O}^{2-}}\right)
$$

This is the similar concept with the standard formal potential in the equation (7). Also the 
standard formal free energy of the following reaction, $\Delta G^{0^{\prime}}(12)$, is available the reported thermodynamical data ${ }^{10}$.

$$
\mathrm{Li}(\mathrm{l})+\frac{1}{2} \mathrm{O}_{2}(\mathrm{~g})=\mathrm{Li}_{2} \mathrm{O}(\mathrm{s})
$$

Then the free energy of the reaction shown in the equation (13), $\Delta G^{0^{\prime}}(13)$, is calculated using $\Delta G^{0^{\prime}}(8)$ and $\Delta G^{0^{\prime}}(12)$.

$$
\begin{aligned}
& 2 \mathrm{Li}(\mathrm{l})+\frac{1}{2} \mathrm{O}_{2}(\mathrm{~g})=2 \mathrm{Li}^{+}+\mathrm{O}^{2-} \\
& \Delta G^{0^{\prime}}(13)=\Delta G^{0^{\prime}}(12)-\Delta G^{0^{\prime}}(8)
\end{aligned}
$$

$\Delta G^{0^{\prime}}$ (13) is therefore obtained from experimental data of $\Delta G^{0^{\prime}}(8)$. In addition, the standard formal entropy of formation, $\Delta S^{0^{\prime}}(13)$, and the standard formal enthalpy of formation, $\Delta H^{0^{\prime}}(13)$ is calculated according to the equations (15) and (16) .

$$
\begin{aligned}
& \Delta S^{0^{\prime}}(12)=-\left(\frac{\partial \Delta G^{0^{\prime}}(12)}{\partial T}\right)_{p} \\
& \Delta H^{0^{\prime}}(12)=\Delta G^{0^{\prime}}(12)+T \Delta S^{0^{\prime}}(12)
\end{aligned}
$$

The obtained formal thermodynamic quantities are shown in Table 2 . The error values are 
the $95 \%$ confidence intervals. Table 2 shows that $\Delta H^{0^{\prime}}(13)$ is almost constant in all the systems. However, $\Delta S^{0^{\prime}}(13)$ obtained in the neat $\mathrm{LiCl}$ is remarkably different from that in the melt containing $\mathrm{KCl}$, which is attributed to the difference of the structure of oxide ion in the melts.

The equation (13) is divided into the following two half equations.

Anode: $\frac{1}{2} \mathrm{O}_{2}+2 \mathrm{e}^{-}=\mathrm{O}^{2-}$

Cathode: $\mathrm{Li}^{+}+\mathrm{e}^{-}=\mathrm{Li}$

Therefore the standard free energy of the equation (13) is given by the equation:

$$
\Delta G^{0}(13)=-2 F\left(E_{\mathrm{O}_{2} / \mathrm{O}^{2-}}^{0}-E_{\mathrm{Li}^{+} / \mathrm{Li}}^{0}\right)
$$

where $E_{\mathrm{Li}^{+} / \mathrm{Li}}^{0}$ is the standard potential of $\mathrm{Li}^{+} / \mathrm{Li}$. However, those values cannot be measured experimentally. Here standard formal free energy, $\Delta G^{0^{\prime}}(13)$, is expressed by the equation $(20)^{9}$.

$$
\Delta G^{0^{\prime}}(13)=\Delta G^{0}(13)-R T \ln \frac{\gamma_{\mathrm{O}_{2}}^{1 / 2}}{\gamma_{\mathrm{O}^{2-}} \cdot \gamma_{\mathrm{Li}^{+}}^{2}}
$$

Thus $\Delta G^{0^{\prime}}(13)$ is given by the equation: 


$$
\Delta G^{0^{\prime}}(12)=-2 F\left(E_{\mathrm{O}_{2} / \mathrm{O}^{2-}}^{0^{\prime}}-E_{\mathrm{Li}^{+} / \mathrm{Li}}^{0^{\prime}}\right)
$$

where $E_{\mathrm{Li}^{+} / \mathrm{Li}}^{0^{\prime}}$ is the standard formal potential of $\mathrm{Li}^{+} / \mathrm{Li}$, which is given by the following equation.

$$
\begin{aligned}
E_{\mathrm{Li}^{+} / \mathrm{Li}}^{0^{\prime}} & =E_{\mathrm{Li}^{+} / \mathrm{Li}}-\frac{R T}{F} \ln X_{\mathrm{Li}^{+}} \\
& =-\frac{R T}{F} \ln X_{\mathrm{Li}^{+}}
\end{aligned}
$$

$E_{\mathrm{Li}^{+} / \mathrm{Li}}$ is defined to be zero in this study.

Consequently, the standard formal potential of $\mathrm{O}_{2} / \mathrm{O}^{2-}, E_{\mathrm{O}_{2} / \mathrm{O}^{-2}}^{0^{-}}\left(\mathrm{vs} . \mathrm{Li}^{+} / \mathrm{Li}\right)$, is obtained using the equations (11), (14), (21) and (22). Here the solubility of $\mathrm{Li}_{2} \mathrm{O}$ was used as the mole fraction of oxide ion, $X_{\mathrm{O}^{2-}}$. The result obtained in each LiCl-KCl melt is shown in Table 3 and Figure 5. The standard formal potential of $\mathrm{O}_{2} / \mathrm{O}^{2-}$ increases with the decrease of temperature and the increase of the mole fraction of $\mathrm{LiCl}$ in the melt.

\section{Conclusion}

The solubilities of $\mathrm{Li}_{2} \mathrm{O}$ in molten $\mathrm{LiCl}-\mathrm{KCl}$ systems were determined in the 
temperature range of 673 to $923 \mathrm{~K}$. The melt with higher content of $\mathrm{LiCl}$ in molten

$\mathrm{LiCl}-\mathrm{KCl}$ systems has higher solubility of $\mathrm{Li}_{2} \mathrm{O}$. The neat $\mathrm{LiCl}$ has highest solubility of

$\mathrm{Li}_{2} \mathrm{O}$ and it is $12.0 \pm 0.2 \mathrm{~mol} \%$ at $923 \mathrm{~K}$.

The standard formal potential of $\mathrm{O}_{2} / \mathrm{O}^{2-}$ evaluated from the results in the present study linearly increases with the decrease of the temperature and the increase of the mole

fraction of $\mathrm{LiCl}$ in the melt. 


\section{Literature Cited}

(1) Chen, G. Z.; Flay, D. J.; Farthing, T. W. Direct electrochemical reduction of titanium dioxide to titanium in molten calcium chloride. Nature 2000, 407, 361-364.

(2) Usami, T.; Kurata, M.; Inoue, T.; Sims, H. E.; Beetham, S. A.; Jenkins, J. A. Pyrochemical reduction of uranium dioxi bvde and plutonium dioxide by lithium metal. $J$.

Nucl. Mater. 2002, 300, 15-26.

(3) Goto, T.; Araki, Y.; Hagiwara, R. Oxygen gas evolution on boron-doped diamond electrode in molten chloride systems. Electrochem. Solid-State Lett. 2006, 9, D5-D7.

(4) Sakamura, Y.; Kurata, M.; Inoue, T. Electrochemical reduction of $\mathrm{UO}_{2}$ in molten $\mathrm{LiCl}$ and $\mathrm{LiCl}-\mathrm{KCl}$ eutectic. $7^{\text {th }}$ International Symposium on Molten Salts Chemistry \& Technology, Proceedings 2005, 2, 597-601.

(5) Levin, E. M.; Robbins, C. R.; McMurdie, H. F. Phase Diagrams for Ceramists 1969

Supplements; National Bureau of Standards: American Ceramic Society, Inc., 1969. 
(6) Yasuda, K.; Nohira, T.; Amezawa, K.; Ogata, Y. H.; Ito, Y. Mechanism of direct

electrolytic reduction of solid $\mathrm{SiO}_{2}$ to $\mathrm{Si}$ in molten $\mathrm{CaCl}_{2}$. J. Electrochem. Soc. 2005, 152,

D69-D74.

(7) Levin, E. M.; Robbins, C. R.; McMurdie, H. F. Phase Diagrams for Ceramists;

National Bureau of Standards: American Ceramic Society, Inc., 1964.

(8) Sakamura, Y.; Kurata, M.; Inoue, T. Electrochemical Reduction of $\mathrm{UO}_{2}$ in Molten $\mathrm{CaCl}_{2}$ or

LiCl. J. Electrochem. Soc. 2006, 153, D31-D39.

(9) Nakajima, H.; Nohira, T.; Ito, Y. Thermodynamic investigations of a hydrogen electrode reaction in a molten LiCl-KCl-LiH system. Electrochem. Solid-State Lett. 2002, 5, E17-E20.

(10) FACT-web, http://www.crct.polymtl.ca/fact/., CRCT, 1996. 
Table 1 Temperature dependence of the solubility products of $\mathrm{Li}_{2} \mathrm{O}$ in molten $\mathrm{LiCl}-\mathrm{KCl}$ systems.

\begin{tabular}{ccc}
\hline $\mathrm{LiCl}: \mathrm{KCl}$ & $T / \mathrm{K}$ & $\ln K_{\mathrm{sp}}$ \\
\hline $100: 0$ & $873-923$ & $-(2.44 \pm 0.47) \times 10^{3} T^{-1}+0.52 \pm 0.01$ \\
$90: 10$ & $823-923$ & $-(0.41 \pm 0.14) \times 10^{3} T^{-1}-2.17 \pm 0.01$ \\
$75: 25$ & $773-873$ & $-(1.79 \pm 0.35) \times 10^{3} T^{-1}-1.46 \pm 0.03$ \\
$58.5: 41.5$ & $673-823$ & $-(2.39 \pm 0.29) \times 10^{3} T^{-1}-2.43 \pm 0.03$ \\
\hline
\end{tabular}

* The error values are the $95 \%$ confidence intervals. 
Table 2 Thermodynamic data for the reaction (13) : $2 \mathrm{Li}(\mathrm{l})+1 / 2 \mathrm{O}_{2}(\mathrm{~g}) \rightarrow 2 \mathrm{Li}^{+}+\mathrm{O}^{2-}$.

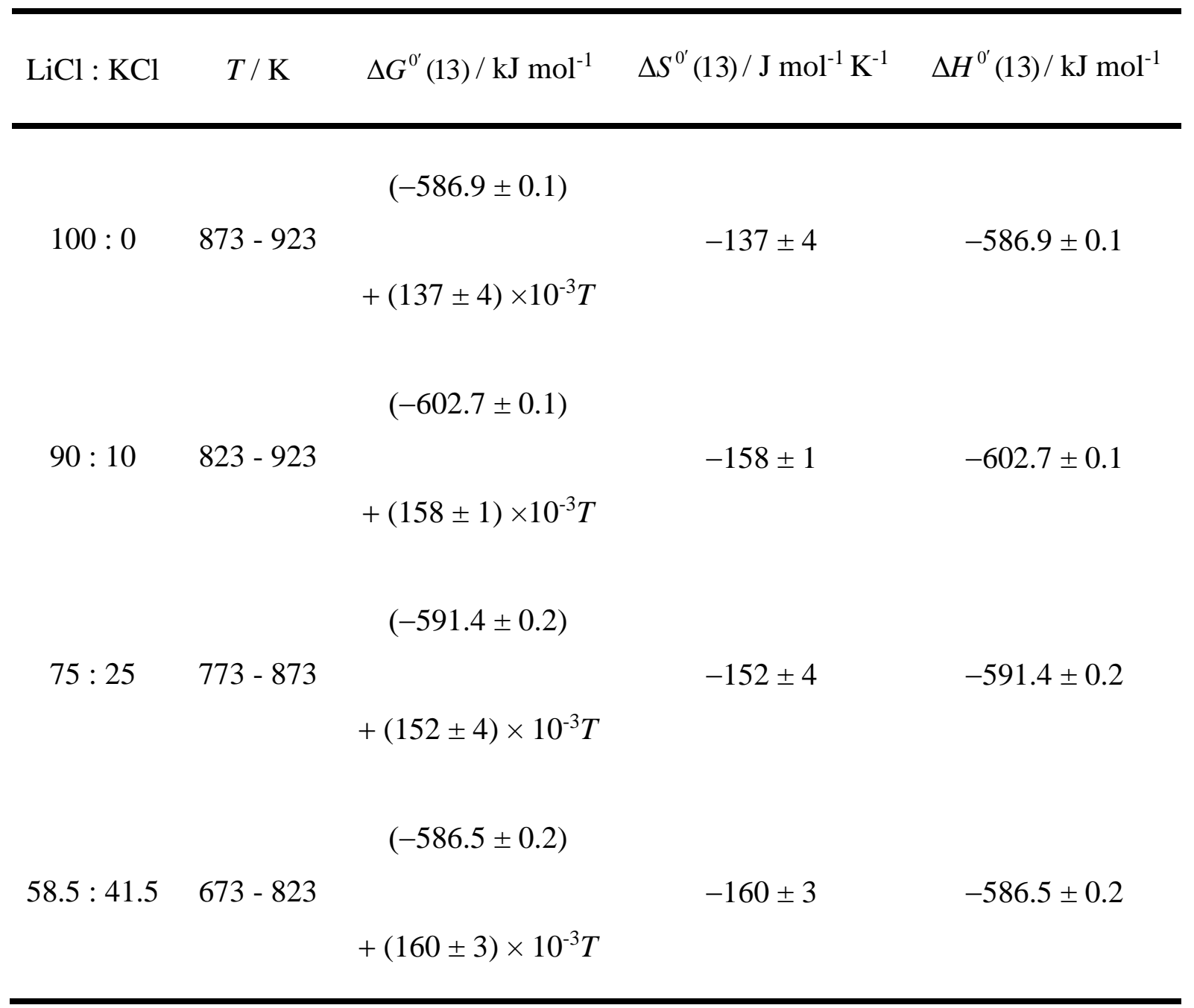

* The error values are the $95 \%$ confidence intervals. 
Table 3 Standard formal potential of $\mathrm{O}_{2} / \mathrm{O}^{2-}$ in molten $\mathrm{LiCl}-\mathrm{KCl}$ systems.

\begin{tabular}{ccc}
\hline $\mathrm{LiCl}: \mathrm{KCl}$ & $T / \mathrm{K}$ & $E_{\mathrm{O}_{2} / \mathrm{O}^{2-}}^{\mathrm{O}^{\prime}} / \mathrm{V} \mathrm{vs} . \mathrm{Li}^{+} / \mathrm{Li}$ \\
\hline $100: 0$ & $873-923$ & $(-7.08 \pm 0.24) \times 10^{-4} T+(3.042 \pm 0.001)$ \\
$90: 10$ & $823-923$ & $(-8.11 \pm 0.10) \times 10^{-4} T+(3.124 \pm 0.001)$ \\
$75: 25$ & $773-873$ & $(-7.70 \pm 0.21) \times 10^{-4} T+(3.078 \pm 0.001)$ \\
$58.5: 41.5$ & $673-823$ & $(-7.90 \pm 0.16) \times 10^{-4} T+(3.042 \pm 0.001)$ \\
\hline
\end{tabular}

* The error values are the $95 \%$ confidence intervals. 


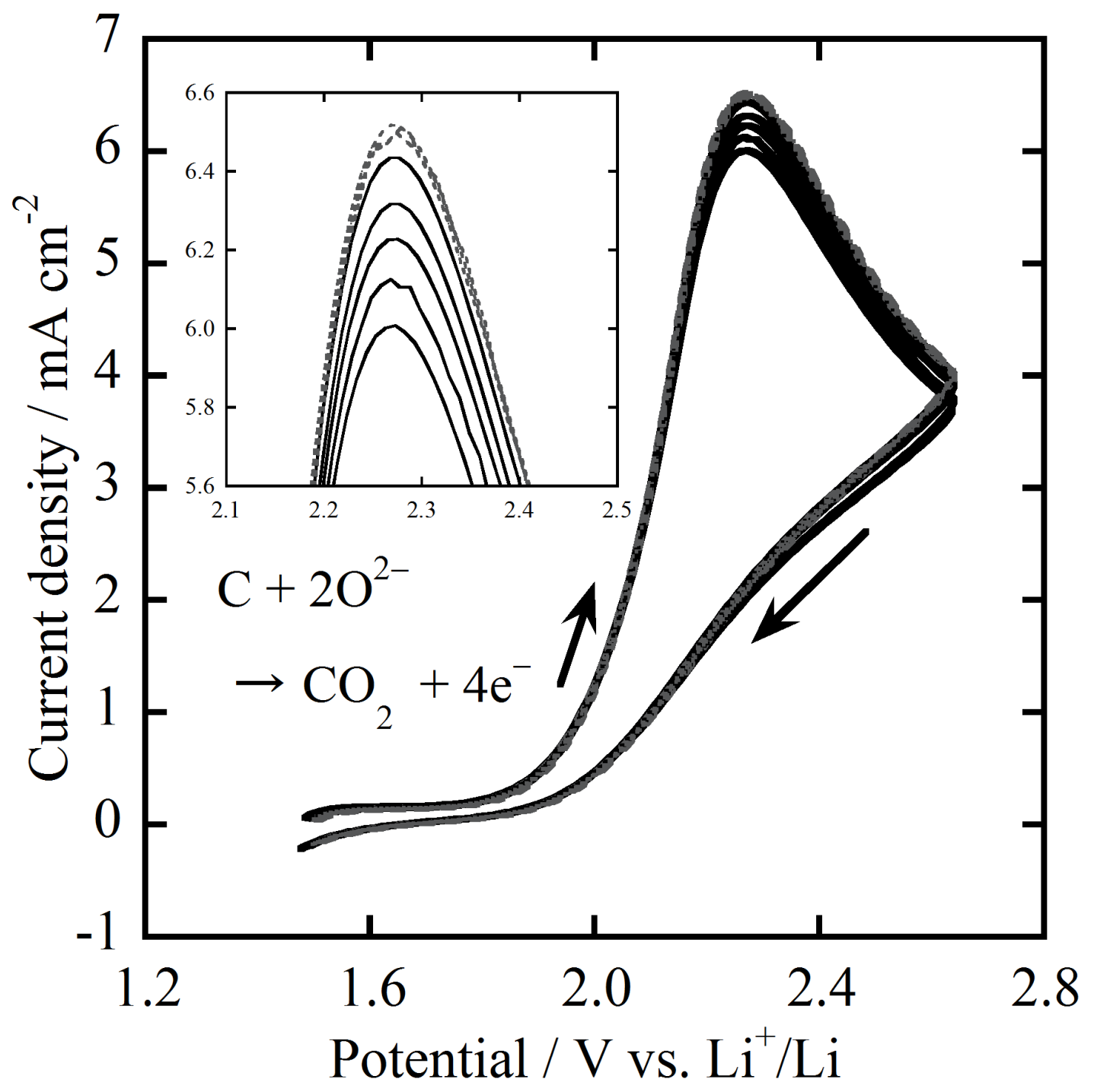

Figure 1 Cyclic voltammograms of a glassy carbon rod in eutectic $\mathrm{LiCl}-\mathrm{KCl}$ (58.5: 41.5) with the addition of $\mathrm{Li}_{2} \mathrm{O}$ (Solid line; 0.975, 1.000, 1.025, 1.050, 1.100 mol\%, Dotted line; $1.150,1.200,1.225 \mathrm{~mol} \%$ ) at $773 \mathrm{~K}$. Scan rate is $0.2 \mathrm{~V} \mathrm{~s}^{-1}$. The inset is the close-up drawing around the current density peaks. 


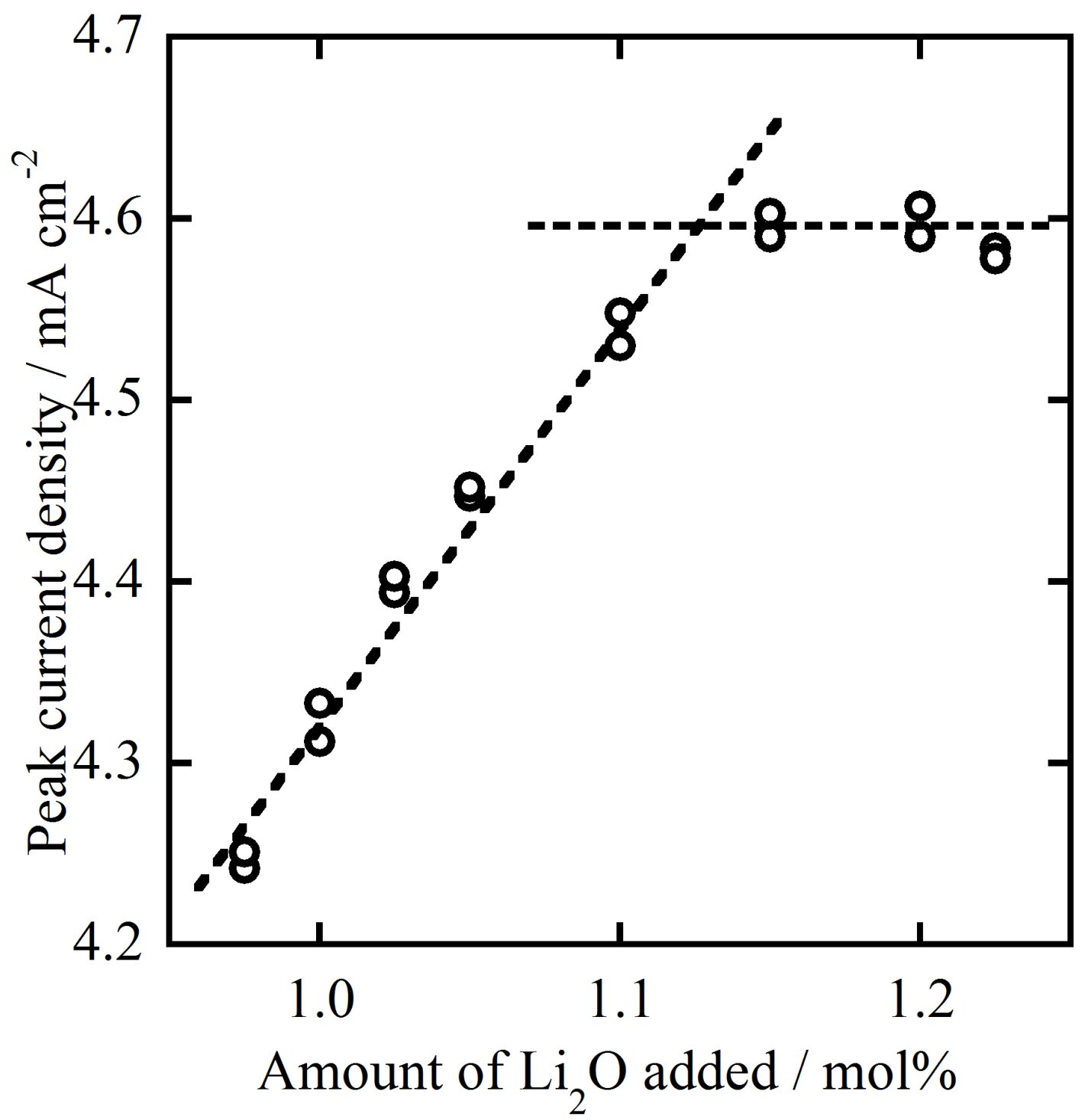

Figure 2 The peak currents against the amount of $\mathrm{Li}_{2} \mathrm{O}$ added in the melt determined from cyclic voltammograms of a glassy carbon electrode in eutectic LiCl-KCl (58.5: 41.5) at 773 K. 


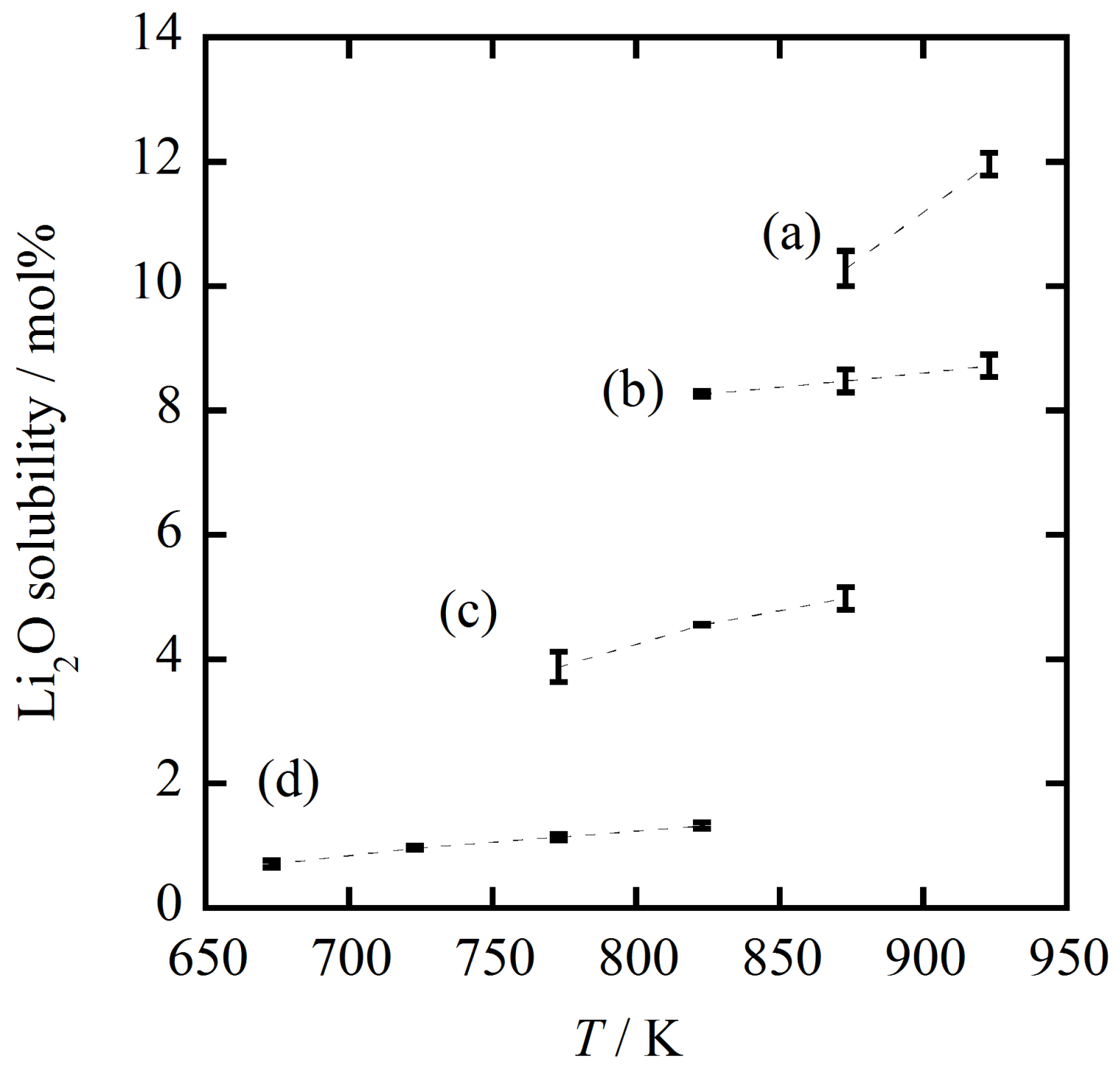

Figure 3 Solubilities of $\mathrm{Li}_{2} \mathrm{O}$ in molten $\mathrm{LiCl}-\mathrm{KCl}$ systems $[\mathrm{LiCl}: \mathrm{KCl}=$ (a) $100: 0$, (b) 90 :

10 , (c) $75: 25$, (d) $58.5: 41.5]$. 


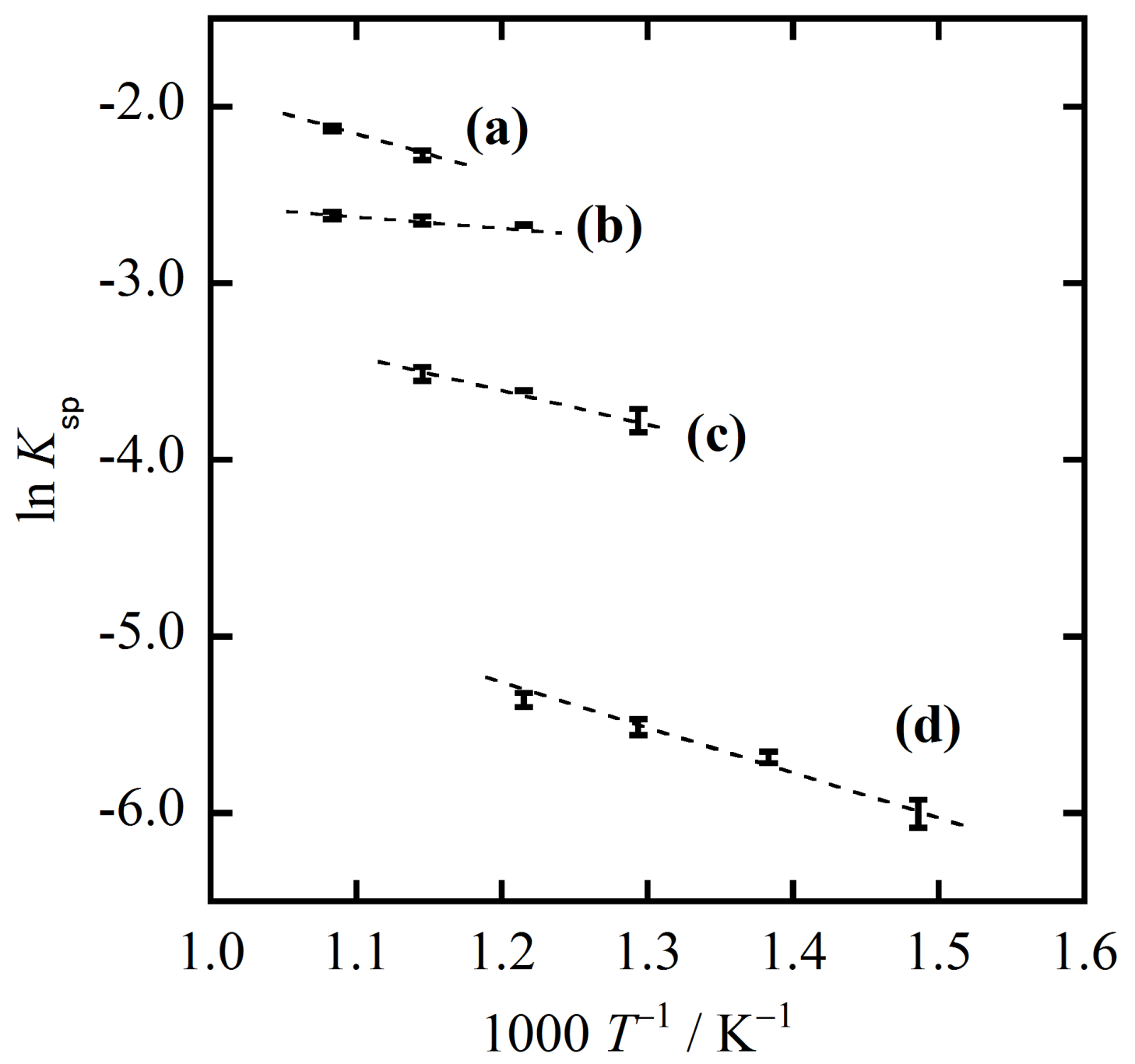

Figure 4 The relationship between temperature and the solubility products of $\mathrm{Li}_{2} \mathrm{O}$ in molten $\mathrm{LiCl}-\mathrm{KCl}$ systems [LiCl : KCl = (a) $100: 0$, (b) $90: 10$, (c) $75: 25$, (d) $58.5: 41.5$ ]. 


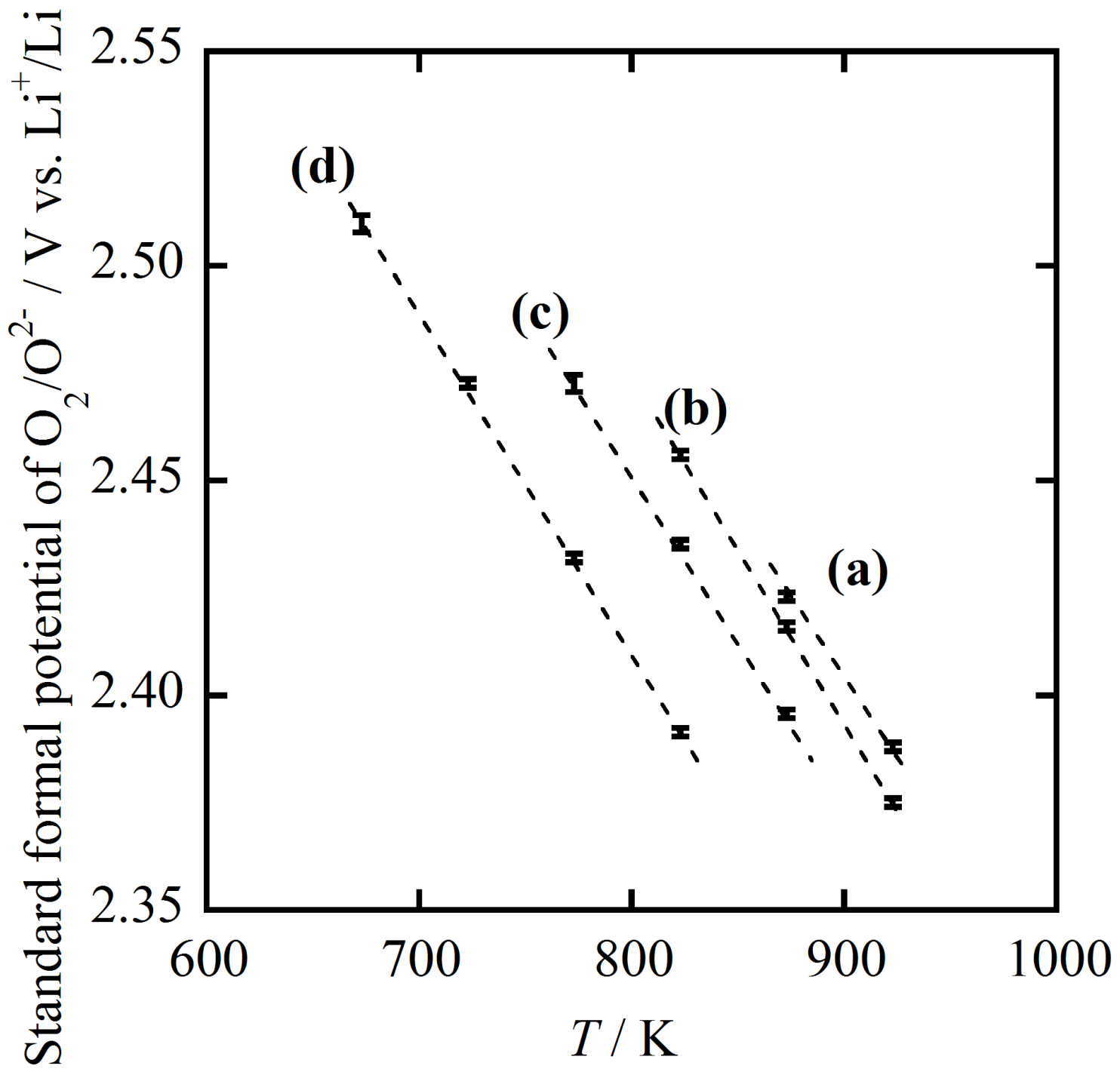

Figure 5 The standard formal potential of $\mathrm{O}_{2} / \mathrm{O}^{2-}$ in molten $\mathrm{LiCl}-\mathrm{KCl}$ systems $[\mathrm{LiCl}: \mathrm{KCl}=$ (a) $100: 0$, (b) $90: 10$, (c) $75: 25$, (d) $58.5: 41.5]$. 